\title{
Response of Foliar Application of Micronutrients to Reproductive Parameters of Guava (Psidium guajava L.)
}

\author{
Sachin, Arvind Kumar, Vipin Kumar*, Yogesh Kumar and Mukesh Kumar \\ Sardar Vallabhbhai Patel University of Agriculture \& Technology, \\ Meerut-250 110 (UP), India \\ *Corresponding author
}

\section{A B S T R A C T}

\section{Keywords}

Psidium gujava,

Foliar application,

Zinc, Boron and

Copper

Article Info

Accepted:

07 September 2019

Available Online:

10 October 2019
The field experiment was carried to evaluate the effect of foliar application of micronutrients viz. zinc, boron and copper in single and different combinations on guava (Psidium guajava L.) cv. Lalit for various reproductive parameters, at Horticulture Research Centre of Sardar Vallabhbhai Patel University of Agriculture \& Technology, Modipuram, Meerut, U.P. India during 2018-19. The experiment was laid out in Randomized Block Design comprised eight treatments with three replications. The maximum number of flowers per shoot (29.87), fruit set percentage $(79.28 \%)$ and fruit retention percentage $(63.20 \%)$ were found in treatment $\mathrm{T}_{8}$ (Zinc sulphate $1.0 \%$ + Borax $1.0 \%$ + Copper sulphate $1.0 \%$ ) whereas the minimum values of above mentioned characters were observed in $\mathrm{T}_{1}$ (control). The maximum fruit drop percentage $(50.53 \%)$ and days to fruit maturity (130.33 days) were recorded in $\mathrm{T}_{1}$ (control). However the minimum fruit drop percentage $(36.8 \%)$ and days to fruit maturity $(116.33$ days) was recorded with foliar application of Zinc sulphate $1.0 \%+$ Borax $1.0 \%$ + Copper sulphate $1.0 \%\left(\mathrm{~T}_{8}\right)$.

\section{Introduction}

The Guava is one of the most common and important fruit crop cultivated all over India. It is fourth most important fruit crop in area and production after mango, banana and citrus. It is classified under genus Psidium which contains 150 species, but only Psidium guajava exploited commercially. It was introduced in $17^{\text {th }}$ century in India by Portuguese people. Guava is hardy, prolific bearer and remunerative fruit. This fruit is considered to be a poor man's apple because of its high nutritive value and comparatively low price. Guava is rich source of vitamin C, vitamin A, vitamin B2 (Riboflavin) and minerals like calcium, phosphate and iron. The vitamin C content of Guava fruit is 212 
$\mathrm{mg} / 100 \mathrm{~g}$ and pectin content (1.15\%). Guava fruit is also utilized to make products like jam, jelly, cheese, ice-cream and toffee (Bagali et al., 1993).

Micronutrients play an important role in production and its deficiency leads in lowering the productivity. Guava plants also show micronutrient deficiency and could be responsible for lesser yield and quality. Foliar feeding of nutrients to fruit plants has gained much importance in recent years which is quite economical and obviously an ideal way of evading the problems of nutrients availability and supplementing the fertilizers to the soil. Nutrients like nitrogen, phosphorus and potassium play a vital role in promoting the plant vigor and productivity, whereas micronutrients like zinc, boron, copper and iron perform a specific role in the growth and development of plant, quality produce and uptake of nutrients. Zinc is a constituent of some enzymes and possibly takes part in synthesis on Indole acetic acid in plant. Boron plays an important role in flowering, fruiting, photosynthesis, hormone movement and cell division, differentiation and development, sugar translocation, pollen germination, pollen tube growth and active salt absorption (Baranwal et al., 2017). Copper is one of the micronutrients needed in very small quantities by plants. Copper activates some enzymes in plants which are involved in lignin synthesis and it is essential in several enzyme systems. It is also required in the process of photosynthesis and assist in plant metabolism of carbohydrates and proteins (Zagade et al., 2017).

\section{Materials and Methods}

The experiment was conducted on well established orchard of five years old Lalit guava trees at Horticultural Research Centre of Sardar Vallabhbhai Patel University of Agriculture and Technology, Modipuram,
Meerut (Uttar Pradesh). The trees are planted at $3.0 \times 3.0 \mathrm{~m}$ spacing. The experiment was laid out in Randomized Block Design (RBD) with eleven treatments replicated thrice. The treatments comprised of Zinc Sulphate - 1.0\% (T2), Copper sulphate (1.0\%) (T3), Borax $(1.0 \%)(\mathrm{T} 4)$, Zinc sulphate $(1.0 \%)+$ Copper sulphate $(1.0 \%)(\mathrm{T} 5)$, Zinc sulphate $(1.0 \%)+$ Borax (1.0\%) (T6), Copper sulphate $(1.0 \%)+$ Borax (1.0\%) (T7), Zinc sulphate $(1.0 \%)+$ Borax (1.0\%) + Copper sulphate (1.0\%) (T8), along with Control (T1). The nutrients were applied through foliar spray feeding. Observation were recorded for number of flower per shoot, fruit set, fruit retention, fruit drop and days to fruit maturity.

\section{Results and Discussion}

A perusal of data in table 1 shows that significant response in maximum number of flowers per shoot $(29.87 \%)$ number of flowers per shoot $(79.28 \%)$ maximum fruit retention $(63.20 \%)$ was recorded with spray of Zinc Sulphate $(1.0 \%)+$ Borax $(1.0 \%)+$ Copper Sulphate (1.0\%) (T8) followed by (T6) Zinc sulphate 1\% + Borax 1.0\% (25.87\%, 77.29\% $\& 59.18 \%$ ) in comparison to control (T1).

Borax response was more positive due to boron which plays an important role in translocation of carbohydrates auxin synthesis to the sink and increased in pollen viability and fertilization. Whereas Zinc Sulphate aids synthesis of plant growth substances and enzyme systems and is essential for promoting certain metabolic reactions. By the foliar application of boron the fruit drop was reduced because boron plays an important role in translocation of carbohydrate and auxin synthesis to sink and increased pollen viability and fertilization. When these three nutrients applied as in combination their synergistic effect enhanced the fruit retention as compared to other treatments (Fig. 1). 
Table.1 Effect of foliar application of micronutrients on reproductive parameters of winter season guava (Psidium guajava L) cv. Lalit.

\begin{tabular}{|c|c|c|c|c|c|}
\hline Treatment & $\begin{array}{l}\text { No. Flowers } \\
\text { Per Shoot }\end{array}$ & Fruit Set (\%) & $\begin{array}{c}\text { Fruit } \\
\text { Retention }(\%)\end{array}$ & $\begin{array}{l}\text { Fruit drop } \\
(\%)\end{array}$ & $\begin{array}{l}\text { Days to fruit } \\
\text { maturity }\end{array}$ \\
\hline $\mathbf{T}_{1}$ Control & 13.93 & 57.36 & 49.47 & 50.53 & 130.33 \\
\hline $\mathrm{T}_{2}$ Zinc sulphate- $\mathbf{1 . 0 \%}$ & 19.13 & 64.44 & 54.06 & 45.94 & 123.00 \\
\hline$T_{3}$ Cooper sulphate- $1.0 \%$ & 16.27 & 63.57 & 51.52 & 48.48 & 125.67 \\
\hline $\mathrm{T}_{4}$ Borax $-1.0 \%$ & 20.20 & 67.67 & 56.04 & 43.96 & 123.67 \\
\hline $\begin{array}{c}T_{5} \text { Zinc sulphate }(1.0 \%)+\text { Copper sulphate } \\
(1.0 \%)\end{array}$ & 23.07 & 72.23 & 58.13 & 41.87 & 121.33 \\
\hline$T_{6}$ Zinc sulphate $(1.0 \%)+$ Borax $(1.0 \%)$ & 25.87 & 77.29 & 59.85 & 40.15 & 118.67 \\
\hline$T_{7}$ Copper sulphate $(1.0 \%)+$ Borax $(1.0 \%)$ & 24.53 & 73.33 & 59.18 & 40.82 & 119.67 \\
\hline $\begin{array}{c}\text { T}_{8} \text { Zinc sulphate }(1.0 \%)+\text { Borax }(1.0 \%)+ \\
\text { Copper sulphate }(1.0 \%)\end{array}$ & 29.87 & 79.28 & 63.20 & 36.80 & 116.33 \\
\hline SEm \pm & 0.24 & 2.55 & 2.64 & 2.64 & 0.76 \\
\hline $\mathrm{CD}(\mathrm{P}=\mathbf{0 . 0 5})$ & 0.70 & 7.47 & 7.73 & 7.73 & 2.23 \\
\hline
\end{tabular}


Fig.1 Effect of foliar application of micronutrients on reproductive parameters of winter season guava (Psidium guajava L) cv. Lalit.

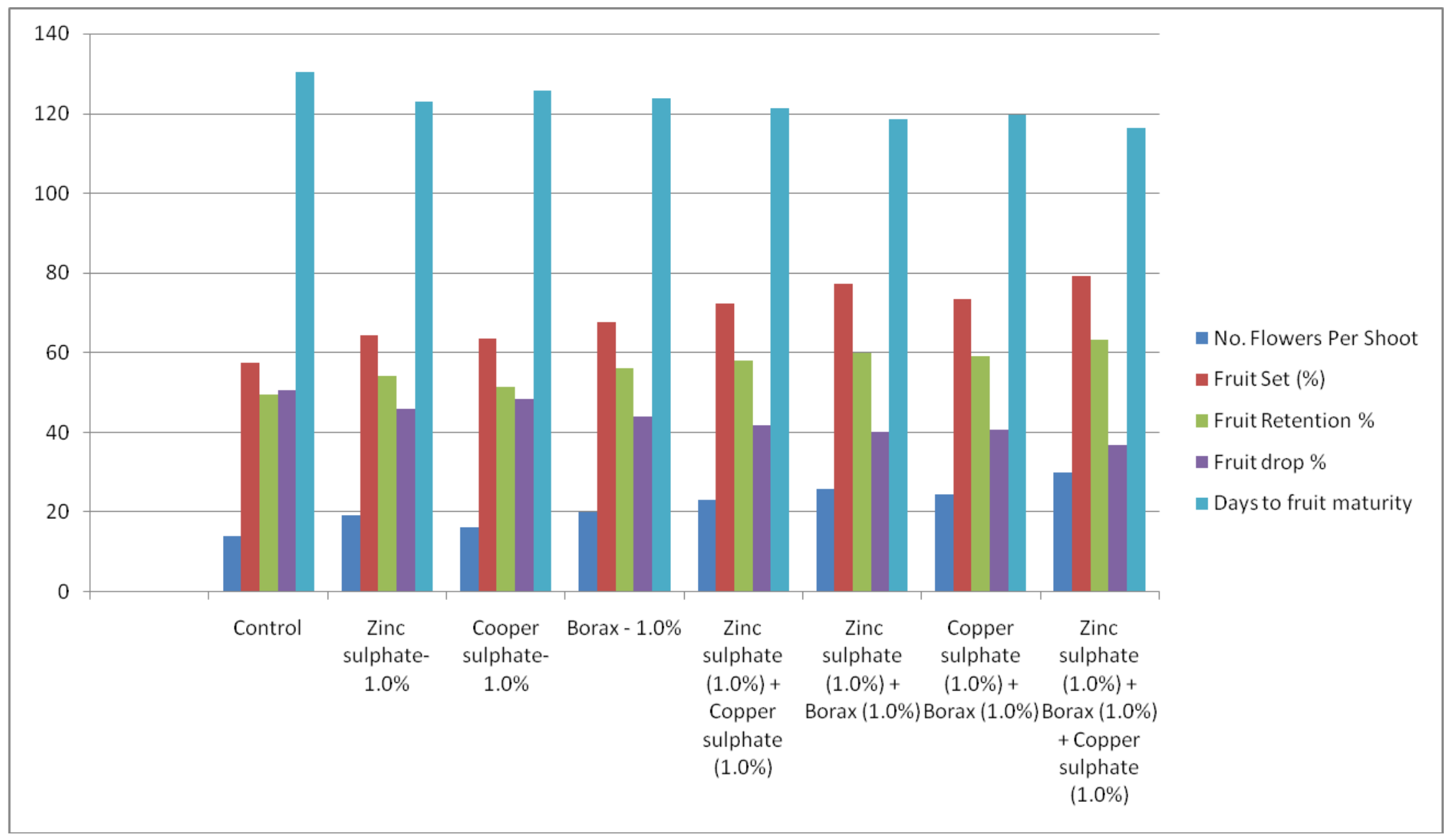


These results are in accordance with the findings of Yadav et al., (2011), Bhatia et al., (2001) and Shrikant et al., (2017) in guava. Similar results were also observed by Jat et al., (2014), Awasthi and Lal (2009) in guava.

The percentage of fruit drop was found to decrease in all the treatments except control. The minimum $(36.80 \%)$ fruit drop was recorded when the plants were sprayed with Zinc sulphate $(1.0 \%)+$ Borax $(1.0 \%)+$ Copper sulphate $(1.0 \%)$ (T8). The results revealed that the zinc has helped in fruit retention because zinc stimulates the synthesis of endogenous auxins. Auxin prevents the abscission and facilitated the ovary to remain attached with the shoot, resulting in lower fruit drop. These results are in conformity with the findings of Parmar et al., (2014).

The minimum days taken to first harvesting of guava (116.33 days) were recorded with $\mathrm{T}_{8}$ [Zinc sulphate (1.0\%)+ Borax (1.0\%)+ Copper sulphate $(1.0 \%)$ ] treatment which was followed by $\mathrm{T}_{6}$ (118.67 days). The maximum days taken to first harvesting (130.33 days) were recorded at control.

It might be recorded due to early flowering and reduced maturity duration which could be attributed to enhancing effect of zinc in enzymatic reaction, cell division as well in growth as advocated by Yadav et al., (2011).

The yield and physical parameters of fruits with respect number of flowers per shoot, fruit set, fruit retention, fruit drop and days to maturity were obtained maximum with the foliar spray of zinc sulphate $1 \%+$ borax $1 \%+$ Copper sulphate $(1.0 \%)$. Therefore, it may be concluded that foliar spray of zinc sulphate $1 \%+$ borax $1 \%+$ Copper sulphate $(1.0 \%)$ can be recommended to the guava growers for obtaining better yield and improve physical parameters of winter season guava fruits.

\section{References}

Awasthi Priya and S. Lal (2009). Effect of calcium, boron and zinc foliar sprays on the yield and quality of guava (Psidium guajava). Pantnagar. J. Res., 7(2): 223-225.

Bagali, A. N. Hulamani N. C. and Sulikeri G. S. (1993). Effect of foliar application of zinc, magnesium and boron on grown and yield of guava (Psidium guajava L.) cv. Sardar. Karnataka J. Agric. Sci., 6(2): 137-141.

Baranwal D. Tomar S. Singh P. J. and Maurya K. J. (2017). Effect of foliar application of zinc and boron on fruit growth, yield and quality of winter season guava (Psidium guajava L.). International Jounral of Current microbiology and applied science 6(9): 1525-1529.

Bhatia, S. K. Yadav, S. Ahlawat V. P. and Dahiya, S. S. (2001). Effect of foliar application of nutrients on the yield and fruit quality of winter season guava cv. L-49. Haryan J. Hort. Sci., 30(1-2): 6-7.

Jat Giriraj and Kacha, H. L. (2014). Response of guava to foliar application of urea and zinc on fruit set, yield and quality. J. Agri. Res., 1(2): 86-91.

Parmar, J. M. Karetha, K. M. and Rathod P. J. (2014). Effect of foliar spray of urea and zinc on growth and flowering attributes of guava (Psidium guajava) cv. Bhavnagar Red. Advc. Res. J. Crop improve, 5(2): 140-143.

Shreekant Ram D. and Kumar Umesh (2017). Effect of foliar application of micronutrient on fruit set, yield attributes and yield of winter season guava (Psidium guajava L.) cv. L-49. International Journal of Pure Applied 
Bio Science, 5 (5): 1415-1419.

Yadav, H. C. Yadav, A. L. Yadav D. K. and Yadav, P.K. (2011). Effect of foliar application of micro-nutrients and $\mathrm{GA}_{3}$ on fruit yield and quality of rainy season guava (Psidium guajava L.) cv. L-49. Plant Archives, 11(1): 147-149.
Zagade, P.M. Munde G.R. and Shirsath A.H. (2017). Effect of foliar application of micronutrient on yield and quality of guava (Psidium guajava L.) cv. Sardar. IOSR- Journal of pharmacy and Biological Science, 12(5): 56-58.

\section{How to cite this article:}

Sachin, Arvind Kumar, Vipin Kumar, Yogesh Kumar and Mukesh Kumar. 2019. Response of Foliar Application of Micronutrients to Reproductive Parameters of Guava (Psidium guajava L.). Int.J.Curr.Microbiol.App.Sci. 8(10): 486-491. doi: https://doi.org/10.20546/ijcmas.2019.810.053 